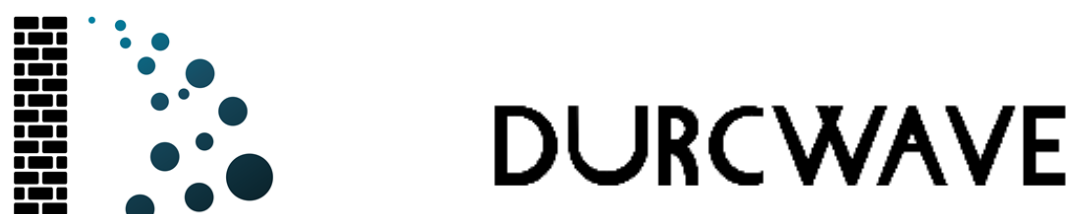

Data Storage Report

DURCWAVE - CIEMito

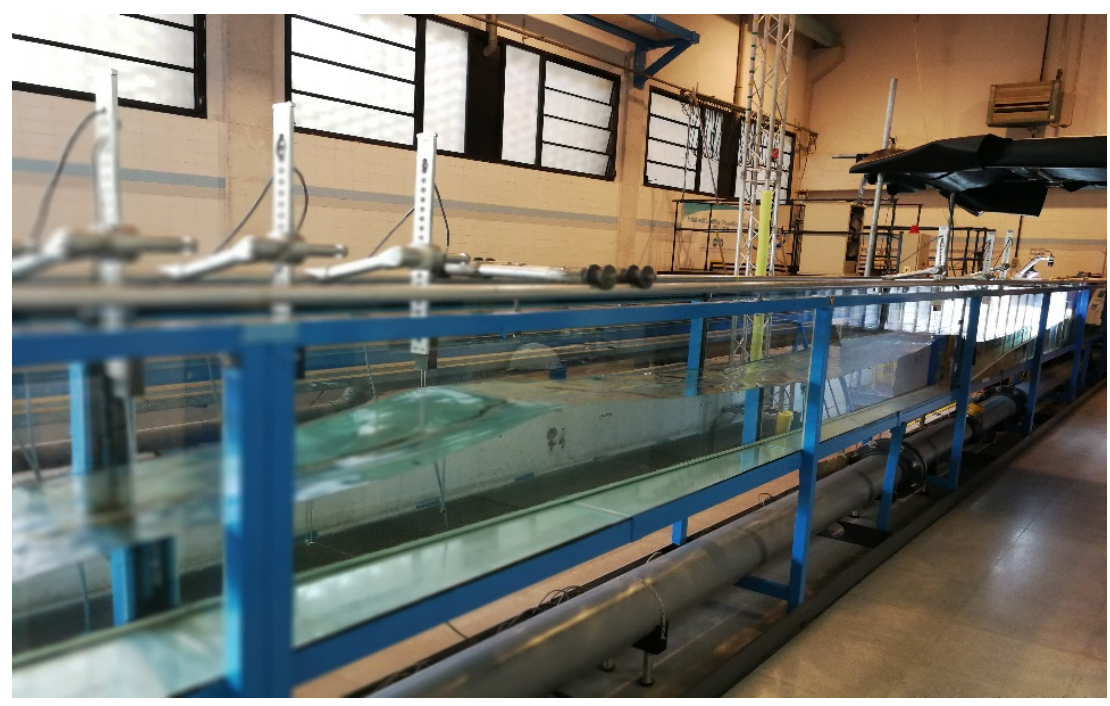




\section{Project Information}

\begin{tabular}{|l|l|}
\hline Acronym & DURCWAVE \\
\hline Title & $\begin{array}{l}\text { amending the Design criteria of URban defences in LECZs through Composite- } \\
\text { modelling of WAVE overtopping under climate change scenarios }\end{array}$ \\
\hline $\begin{array}{l}\text { Experimental } \\
\text { Campaign }\end{array}$ & Small-scale tests in CIEMito wave flume (spring-winter 2019) \\
\hline Location(s) & Universitat Politècnica de Catalunya - BarcelonaTech (UPC) \\
\hline WWW link(s) & durcwave.es \\
\hline Social Media & @durcwave_msca \\
\hline Start date & $01 / 03 / 2019$ \\
\hline End date & $04 / 04 / 2021$ \\
\hline
\end{tabular}

\section{Project Personnel}

\begin{tabular}{|l|l|l|l|l|}
\hline Role & Name & Institution & Email & ORCID-iD \\
\hline $\begin{array}{l}\text { Project } \\
\text { Supervisor }\end{array}$ & $\begin{array}{l}\text { Xavier Gironella I } \\
\text { Cobos }\end{array}$ & UPC & xavi.gironella@upc.edu & $\begin{array}{l}0000-0002- \\
8862-5704\end{array}$ \\
\hline $\begin{array}{l}\text { Main } \\
\text { Researcher }\end{array}$ & $\begin{array}{l}\text { Corrado } \\
\text { Altomare }\end{array}$ & UPC & corrado.altomare@upc.edu & $\begin{array}{l}0000-0001- \\
8817-0431\end{array}$ \\
\hline Technical Staff & $\begin{array}{l}\text { Joaquim } \\
\text { Sospedra Iglesias }\end{array}$ & UPC & Joaquim.sospedra@upc.edu & $\begin{array}{l}0000-0003- \\
4207-7922\end{array}$ \\
\hline $\begin{array}{l}\text { Erasmus } \\
\text { student }\end{array}$ & $\begin{array}{l}\text { Mauro } \\
\text { Campagnola }\end{array}$ & $\begin{array}{l}\text { Politecnico di } \\
\text { Bari }\end{array}$ & m.campagnola@studenti.poliba.it & - \\
\hline $\begin{array}{l}\text { Erasmus } \\
\text { student }\end{array}$ & $\begin{array}{l}\text { Maria Luigia } \\
\text { Robustelli }\end{array}$ & $\begin{array}{l}\text { Università di } \\
\text { Salerno }\end{array}$ & marialuigiarobustelli@gmail.com & - \\
\hline
\end{tabular}

\section{Document objective}

This data storage report describes the project and how data were collected. The data are described so that others can use them.

\section{Acknowledgement}

This project has received funding from the European Union's Horizon 2020 research and innovation programme under the Marie Sklodowska-Curie grant agreement No 792370.

\section{Disclaimer}

This document reflects only the authors' views and not those of the European Community. The information in this document is provided "as is" and no guarantee or warranty is given that the information is fit for any particular purpose. The user thereof uses the information at its sole risk and neither the European Community nor UPC is liable for any use that may be made of the information. 


\section{Document History}

\begin{tabular}{|l|l|l|l|}
\hline Date & Status & Author(s) & Reviewer (s) \\
\hline $05 / 02 / 2020$ & Draft & C. Altomare & - \\
\hline $21 / 03 / 2020$ & Revised & - & X. Gironella, J. Sospedra \\
\hline $23 / 03 / 2021$ & Final (v2) & C. Altomare & - \\
\hline
\end{tabular}

License

cc) (1)

http://creativecommons.org/licenses/by/4.0/ 


\section{Contents}

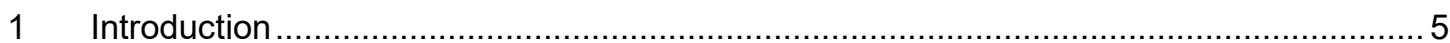

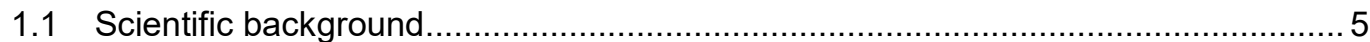

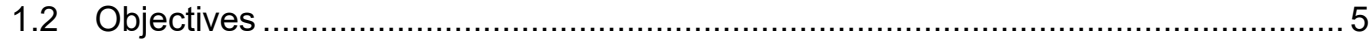

2 Experimental setup

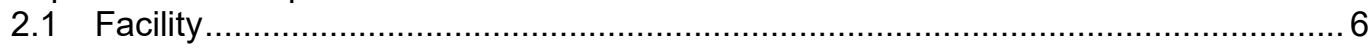

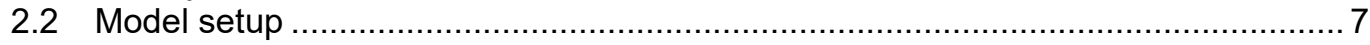

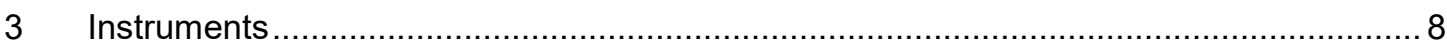

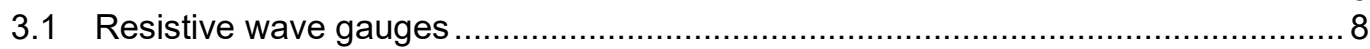

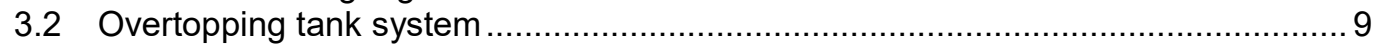

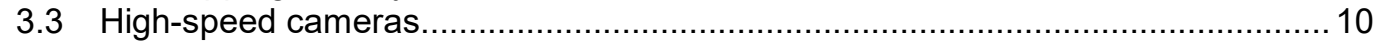

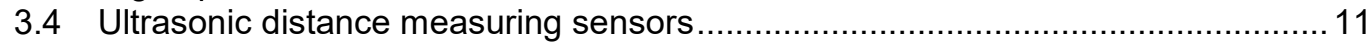

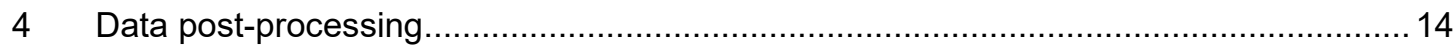

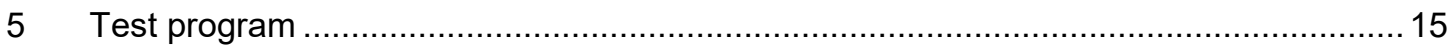

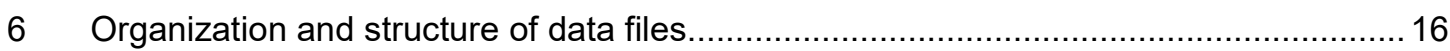

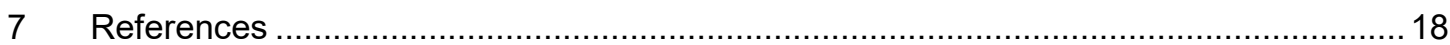




\section{Introduction}

\subsection{Scientific background}

Population, goods and infrastructures in coastal areas are threatened by climate changes and sea-level rise, that cause the increase of phenomena like rogue waves, sea storms and inundations. For this reason, the correct and detailed design of coastal defence structures plays an increasingly important role, making fundamental the meticulous characterization of wave overtopping.

EurOtop (2018) provides a series of design formulas for coastal defences and tolerable limits of overtopping for the safety of people and objects such as vehicles or trains placed nearby the coastline. Key parameters of these formulations and limits are the mean overtopping discharge and the individual maximum volume. However, mean overtopping discharge does not provide information about the quantity of water passing the crest within a single event of the storm, due to the fact that it's defined as the total volume occurred during the sea state divided by the total duration. Sea states characterised by the same average discharge can differ in the individual overtopping volume distributions caused by different boundary sea and foreshore conditions and intrinsic randomness of the phenomenon. Considering two events characterized by the same overall duration and the same total volume, a sea state could consist in many small events or few big individual volumes. This leads, obviously, to different conditions in terms of water velocity and thickness on the sea dike and, in turn, in terms of hazard for people and vehicles.

Relationship between maximum individual overtopping volumes and mean discharges has been widely studied (see EurOtop, 2018). Nevertheless, the importance of overtopping flow properties for coastal safety and structural design has not been fully investigated yet. In such a context, an experimental laboratory campaign was performed in 2019 from May to December at the wave flume CIEMito of the Maritime Engineering Laboratory (LIM) of the Universitat Politècnica de Catalunya - BarcelonaTech (UPC).

\subsection{Objectives}

The experiments aimed at characterizing the flow characteristics associated to the maximum individual overtopping volumes, due to specific storm events with different return periods (Tr). Specifically, the experiments focused on the measurements of overtopping volumes and discharges, in order to find the relation between these parameters with the corresponding overtopping flow velocities and overtopping flow depth, when the maximum overtopping event occurs on a dike during a sea state. The physical model reproduces an urbanized stretch of a town along the Catalan coast (Premià de Mar), approximately $25 \mathrm{~km}$ northeast of Barcelona, where a bike path and a railway run along the coastline, exposed to significant overtopping events every stormy season. 


\section{Experimental setup}

\subsection{Facility}

The CIEMito wave flume (Fig. 2.1) is $17 \mathrm{~m}$ long, $0.37 \mathrm{~m}$ wide and $0.56 \mathrm{~m}$ high. A maximum water depth of $0.36 \mathrm{~m}$ is allowed. The support structure consists of square metal sections with both laterals and bottom walls consisting of tempered glasses $5+5 \mathrm{~mm}$ thick.

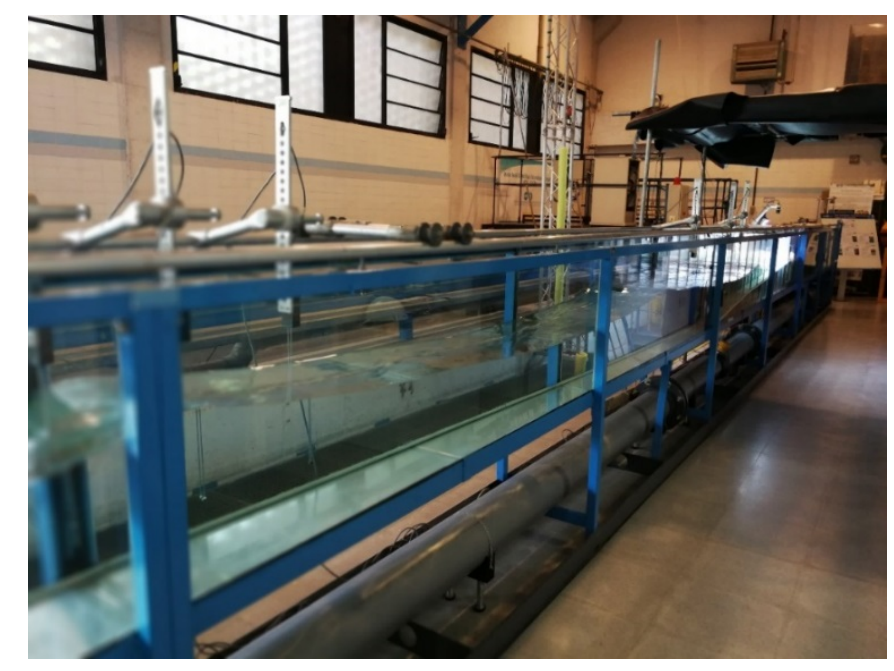

Figure 2.1: CIEMito wave flume

The wave generation system is a piston-type board, made of a vertical panel whose motion is provided by a linear actuator allowing a maximum stroke of $1 \mathrm{~m}$ with a response speed of $1.6 \mathrm{~m} / \mathrm{s}$. The paddle moved backwards and forwards horizontally. Wave generation software was developed at LIM/UPC and allows the generation of both regular and irregular waves with a maximum wave height of $0.28 \mathrm{~m}$ and a maximum peak period of $1.7 \mathrm{~s}$. The flume water filling/emptying is provided by a pumping system and the water level measured manually (Fig. 2.2).

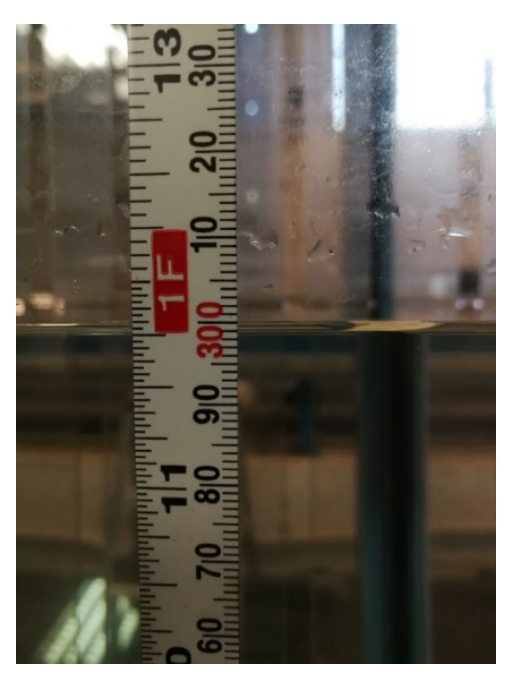

Figure 2.2: Measurement system of SWL: the surface tension effect disturbs the measure. 


\subsection{Model setup}

The model-scale was 1:50, according to Froude's similarity law. A sketch of the model layout is proposed in Figure 2.3 (dimensions are in model scale). The model consists of a 1:n transition slope followed by a 1:m foreshore slope, where $n$ is equal to 8 for $m=15$ and 5 for $m=30$, respectively. A 1:1 smooth dike made of polymethyl methacrylate is placed at the end of the foreshore. Dike height is $0.09 \mathrm{~m}$. Different widths for the promenade (i.e. crest berm) were modelled, namely 0.12 and $0.24 \mathrm{~m}$, to be representative of the different stretches along the coastline. Tested local water depth, freeboard and promenade with are summarized in Table 2.1.

Table 2.1: Geometric characteristics of the tested dike layout.

\begin{tabular}{|c|c|c|c|}
\hline Scale & $\mathbf{h}_{\text {toe }} \mathbf{( m )}$ & $\mathbf{R}_{\mathbf{c}} \mathbf{( m )}$ & Promenade width (m) \\
\hline Model & $0.009-0.019-0.024-0.029$ & $0.81-0.071-0.066-0.061$ & $0.12-0.24$ \\
\hline Prototype & $0.45-0.905-1.2-1.45$ & $4.05-3.55-3.3-3.05$ & $6-12$ \\
\hline
\end{tabular}

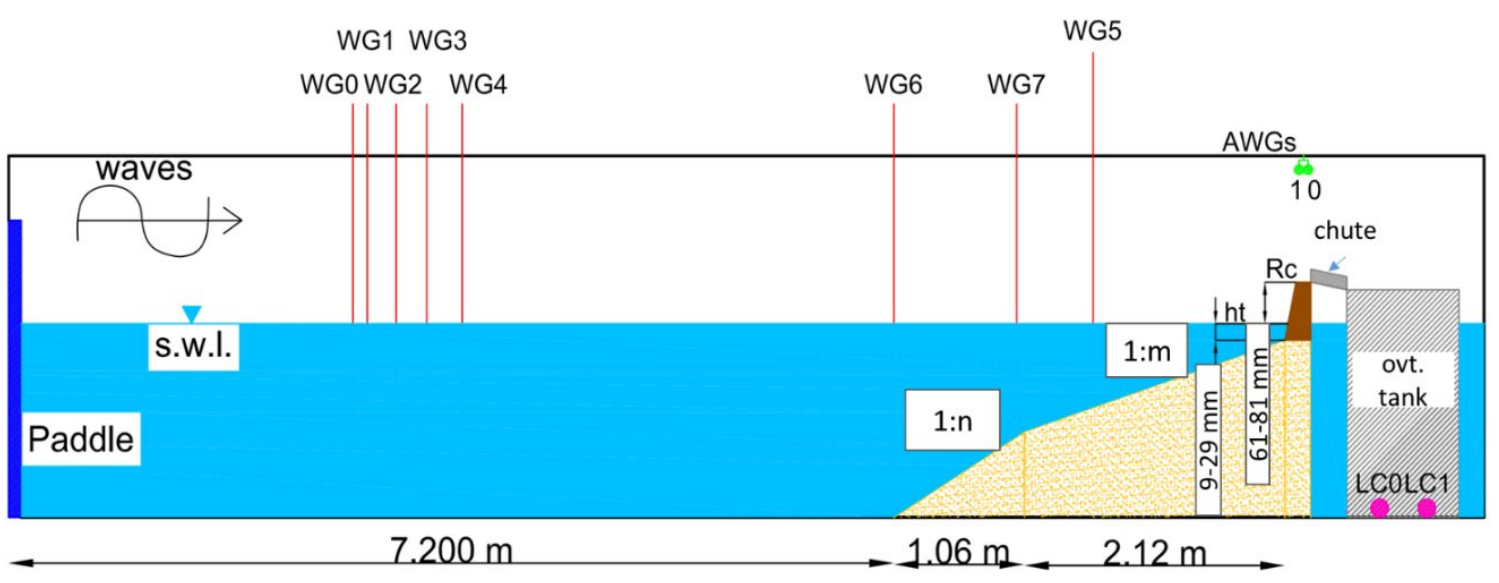

Figure 2.3: CIEMito wave flume - drawing of the longitudinal section (distorted). Dimensions are in model scale (source: Altomare et al., 2020).

Irregular wave tests, employing a JONSWAP spectrum with enhancement factor equal to 3.3, were performed. Each test consisted in approximately 1000 waves. In total 420 tests were conducted. The tested wave conditions were derived from the extreme wave forecast based on data acquired by the buoy of the Puertos del Estado, located outside Barcelona harbour, for different return periods. 


\section{Instruments}

The experimental tests carried out are aimed to measure the following parameters:

- Free surface water elevations: $\eta(\mathrm{m})$;

- Cumulated Volume: $\mathrm{V}_{\text {tot }}\left(\mathrm{m}^{3} / \mathrm{m}\right)$;

- Mean discharge: $\mathrm{q}(\mathrm{l} / \mathrm{s} / \mathrm{m})$, obtained as $\frac{\mathrm{v}_{\text {tot }}}{\mathrm{T}_{\mathrm{p}} \mathrm{N}_{\mathrm{w}}}$;

- Maximum overtopping volume: $\mathrm{V}_{\max }(\mathrm{l} / \mathrm{m})$;

- Velocity of maximum overtopping volume: $\mathrm{u}(\mathrm{m} / \mathrm{s})$;

- Thickness of maximum overtopping volume: $\lambda(\mathrm{m})$

by means of the following instruments:

- 8 resistive Wave gauges (WG0, ..., WG7) for the free-surface water elevation measurement along the channel;

- 2 Load cells - LC0 and LC1 - below the overtopping tank to measure the weight of the overtopping flow, later converted into volume:

- 2 High-speed cameras - CAM_1 and CAM_2 - to measure overtopping flow depths (thickness) and velocities;

- 2 Ultrasonic sensors - AWG1 and AWG0 - on the dike top to measure flow thickness and velocities;

\subsection{Resistive wave gauges}

Eight resistive sensors, of $30 \mathrm{~cm}$ length were placed along the flume (Figure 3.1) to measure the water surface elevation at different location (WG0-WG8), working at a sample frequency of $80 \mathrm{~Hz}$. Distance of the resistive wave gauges with respect to the zero paddle position are reported in Table 3.1.

Table 3.1: Location from paddle of resistive wave gauges (in meters)

\begin{tabular}{|l|l|l|l|l|l|l|l|l|}
\hline Sensor & WG0 & WG1 & WG2 & WG3 & WG4 & WG6 & WG7 & WG5 \\
\hline $\mathrm{x}(\mathrm{m}=15)$ & 2.8 & 2.96 & 3.15 & 3.40 & 3.69 & 7.20 & 8.20 & 9.20 \\
\hline $\mathrm{x}(\mathrm{m}=30)$ & 2.8 & 2.96 & 3.15 & 3.40 & 3.69 & 7.20 & 8.20 & 9.20 \\
\hline
\end{tabular}

They essentially consist of a pair of parallel stainless-steel electrodes connected to a voltage generator. Since the current circulating between the electrodes is proportional to the immersion depth, it is possible, starting from a voltage output signal from the gauges later converted into a digital signal, to determine the instantaneous values of the free surface. When the resistive wave gauges are immersed, the circuit is close determining a voltage difference which can be expressed as: $\Delta V=R i$, where i represents the current intensity and $R$ is the resistance $\left(R=\frac{\rho l}{s}\right)$, where $l$ is the wire length, $s$ the section and $\rho$ is the electric resistivity. The two relationships demonstrate that the voltage difference measured by a voltmeter placed on the gauges is proportional to the immersed length of the wire. Since the wave gauges provide the output signal in Volts, this measure is later converted in metric units by means if the following linear relationship: 
$\eta=V_{0}+\mathrm{kV}$, where $\eta$ is the measure of the oscillation of the free surface in meters, $V$ is the measure of the oscillation of the free surface in Volts, $V_{0}$ is the intercept of the linear conversion relationship in Volts and $\mathrm{k}$ is the angular coefficient of the linear conversion relationship. The linearity of the probes is verifiable through the calibration procedure. The elevation raw signal is acquired with a sampling rate of $80 \mathrm{~Hz}$.

a)

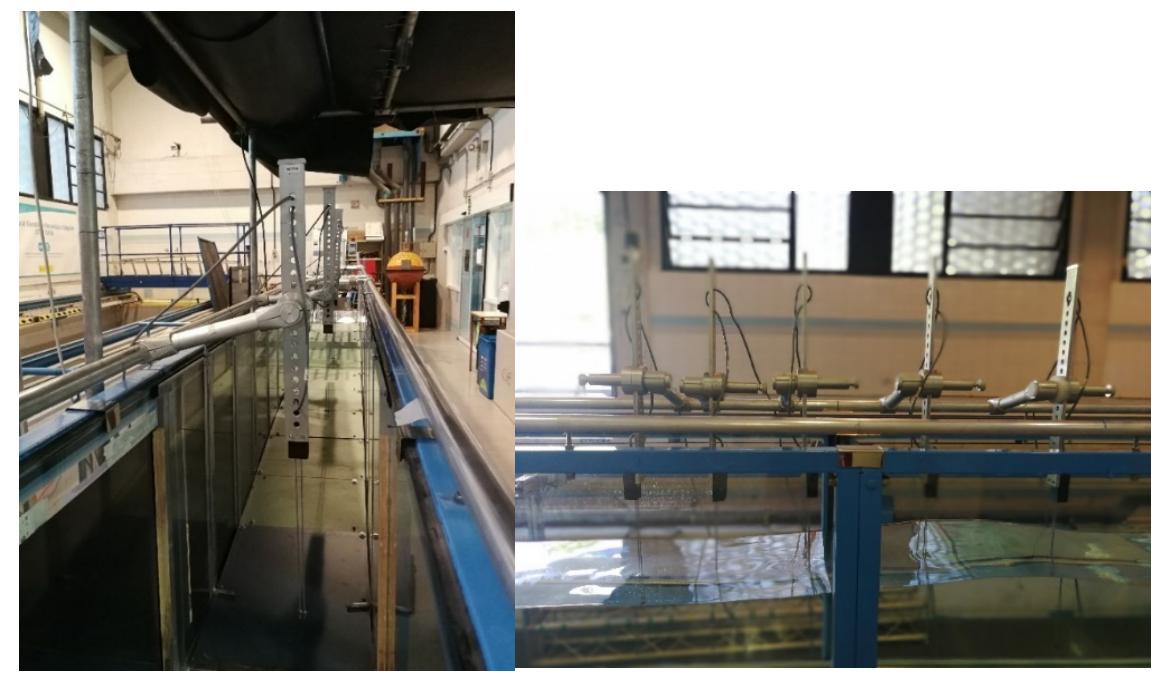

Figure 3.1: Resistive wave gauges, frontal view (a); offshore wave gauges, longitudinal view (b).

\section{$\underline{\text { Calibration }}$}

The transformation function (from voltage to depth) is calibrated due the possible changes in the water conductivity (temperature and salinity concentration effects). An overall calibration from wave height to output voltage can be performed by measuring the change in output voltage, raising or lowering the sensors with respect to the mean water level of the flume.

WaveLab software v.3.676 software developed by University of Aalborg allows calibration and data acquisition of the eight resistive sensors.

\subsection{Overtopping tank system}

The overtopping collection system (Fig. 3.2) is made of a $9.2 \mathrm{~cm}$ large chute which collected the overtopping flows and brought it inside a metallic water tank of 27 l capacity.

Under the tank two beam type load cells (model Z6FC3, rated capacity=50 kg) are installed in order to measure the cumulated water weight, with an acquisition frequency of $20 \mathrm{~Hz}$. A load cell is a transducer which converts the load acting on them into a measurable electrical output. Although there are many varieties of load cells, strain-gage based load cells are the most commonly used type. The Wheatstone bridge circuit is ideal for measuring the resistance changes that occur in strain gages. The gauges themselves are bonded onto a beam or structural member that deforms when weight is applied. The volume is obtained by dividing weight by water density the cumulated volume was obtained. Furthermore, the maximum difference between the measured weight after an overtopping event and the previous weight provided the peak volume. 
a)

b)

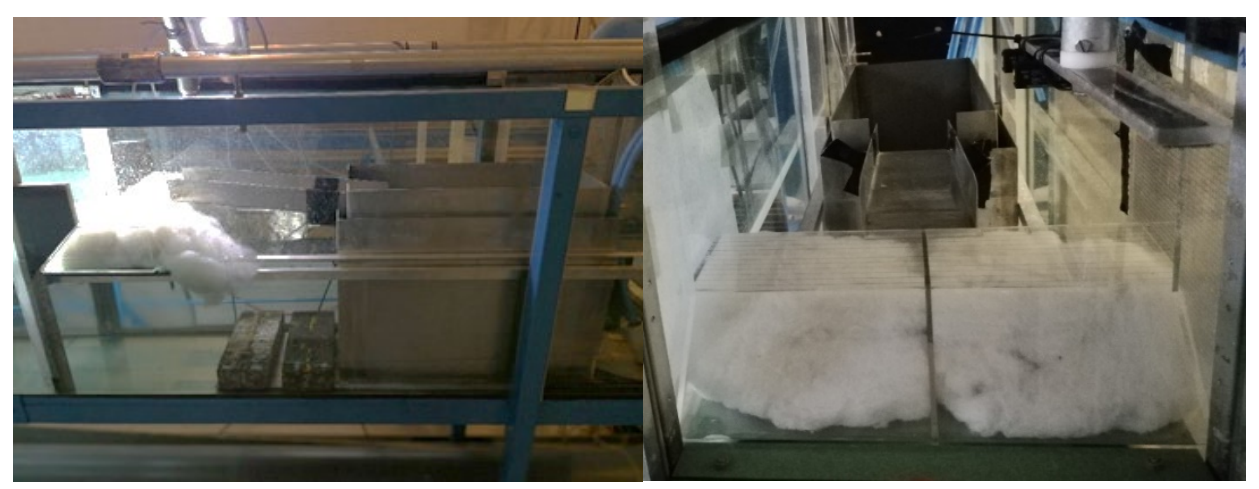

Figure 3.2: Overtopping collection system, longitudinal view (a); frontal view (b).

\section{Calibration}

The load cell calibration is conducted with the softwares CatManEasy v3.4.2 and Excel and with the use of beakers. In order to evaluate its good functioning, variable quantities of water are introduced into the tank and through the CatManEasy software it is verified that the machines calculate the right force; subsequently all the various successions of water injections are plotted in Excel in a graph verifying that the empirical values and those of the machine coincide and that, therefore, it returns in output a regression line with a coefficient of determination of approximately equal to one

\subsection{High-speed cameras}

Overtopping flow depth and overtopping flow velocity were measured by means of redundant systems, composed of two IDS (U-3180CP-M-GL R2.1) high-speed cameras (Figure 3.3) and two ultrasonic sensors. Results were compared and averaged. The high-speed cameras were working at $200 \mathrm{fps}$.

In order to record the video exactly when $V_{\max }$ occurs, due to a good repeatability of the irregular wave temporal series, the same test is repeated two times:

- The execution of the first test allows to detect the peak volume and its instant within the simulated sea state by analysing the signal from load cells;

- The repetition of the test allows to measure wave thicknesses and velocities on the sea-dike by making a video with the two cameras when the peak overtopping volume is expected to occur.

CAM_1: high speed camera 1 is placed on the top of the considered structure. The chute and the promenade are graduated with equally spaced lines $(1 \mathrm{~cm})$.

CAM_2: high speed camera 2 is placed in front of the lateral glass wall, on the side of the sea-dike model, where a transparent paper graduated with $0.5 \mathrm{~cm}$ squares is pasted.

The StreamPix 7x64 Edition SingleCamera / DubleCStreamPix 7.5.0.0 software developed by NorPix, Inc. that allows to capture videos and images from the cameras. 
a)

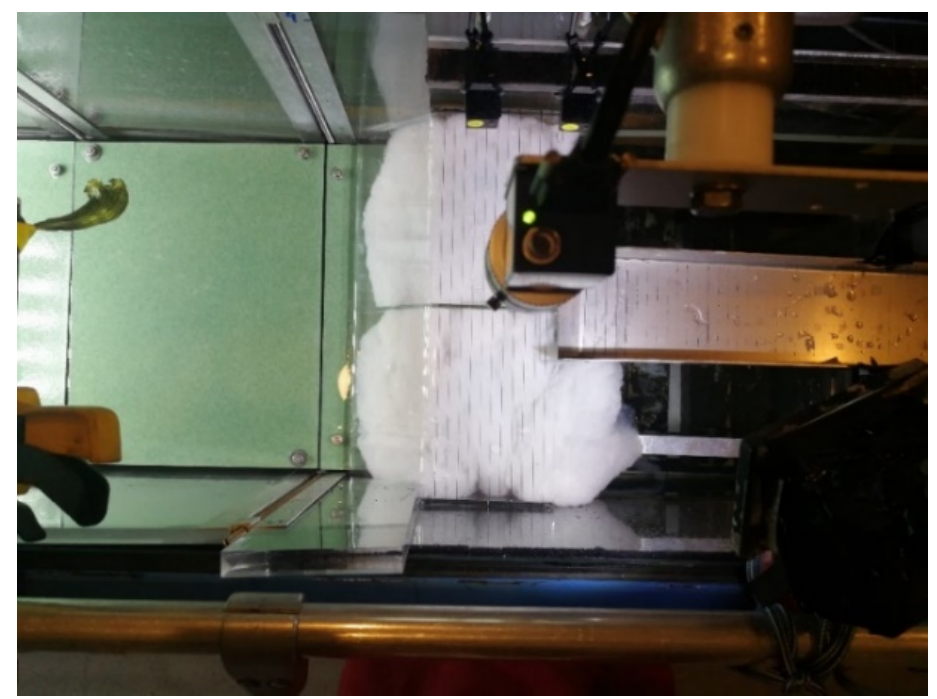

b)

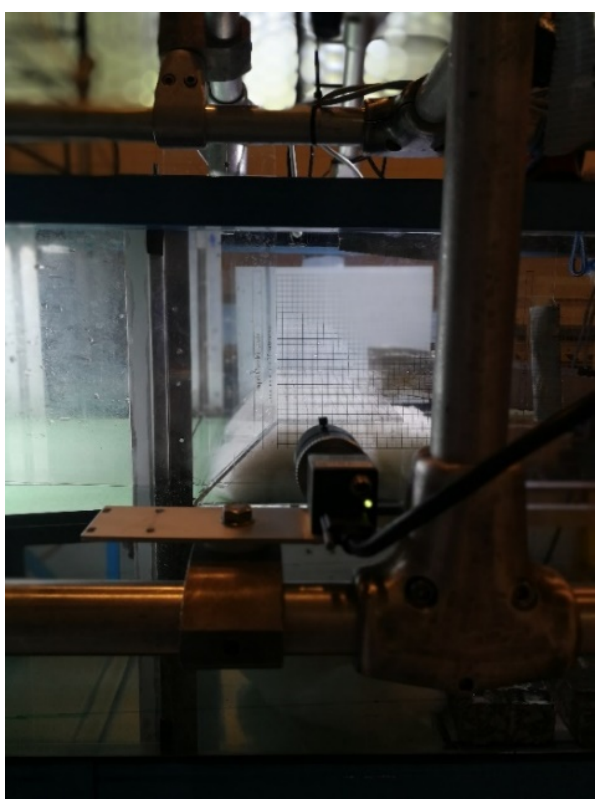

Figure 3.3: High speed camera 1 - flume top view (a); High speed camera 2 - flume lateral view(b).

\subsection{Ultrasonic distance measuring sensors}

Two Baumer ultrasonic sensors (UNDK 20, scanning range $60-400 \mathrm{~mm}$ ) were place on the dike top to measure flow depths (AWG0, AWG1), with resolution $<0.3 \mathrm{~mm}$. AWG 1 is positioned $2.5 \mathrm{~cm}$ far from the dike edge for the crest width of $0.12 \mathrm{~m}$ and $6 \mathrm{~cm}$ for the crest width of $0.24 \mathrm{~cm}$. Distance between AGW1 and AWG0 varied between $5.9 \mathrm{~cm}$ and $9.2 \mathrm{~cm}$. The position of the two ultrasonic sensors and the vertical distance from the crest were optimized case per case to avoid interference between the sensors and optimize accuracy. The AWG raw signal was acquired with a sampling rate of $100 \mathrm{~Hz}$ and filtered in Matlab environment in order to derive overtopping flow depth and velocity on the dike. They are based on the phenomenon of reflection of high-frequency sound waves/acoustic impulses (in the specific case of ultrasound), which are sent, through a piezocrystal, by the instrument. The ultrasound pulse emitted is then reflected by the measurement object, which may be solid, liquid, granular or in powder form (in this case water) and received back, by the same instrument, like an echo. The measurement of the time interval between the emission and the reception allows to calculate, indirectly, the parameters of interest of the waves. This type of sensors allows measurements to be carried out in physical model areas characterized by very small water thicknesses, which are unsuitable for the use of resistive gauges. Another important advantage is the possibility of making measurements with non-intrusive instruments. Ultrasonic sensors reliably detect transparent and other demanding objects where optical technologies fail. Figure 3.5 and Table 3.2 show the ultrasonic sensors technical features. Figure 3.6 illustrates two views of the dike with the ultrasonic sensors installed.

\section{Calibration}

One calibration is needed for every device to correlate the output voltage signal to distances. To vary the distance a parallelepiped-shaped specimen $(0.075 \mathrm{~m} \times 0.075 \mathrm{~m} \times 0.027 \mathrm{~m})$ is placed below the sensor and 
output is measured (Figure 3.4). CatManEasy v3.4.2 software developed by HBM Italia s.r.l. allows calibration of two ultrasonic sensors and two load cells and records their data during the test.

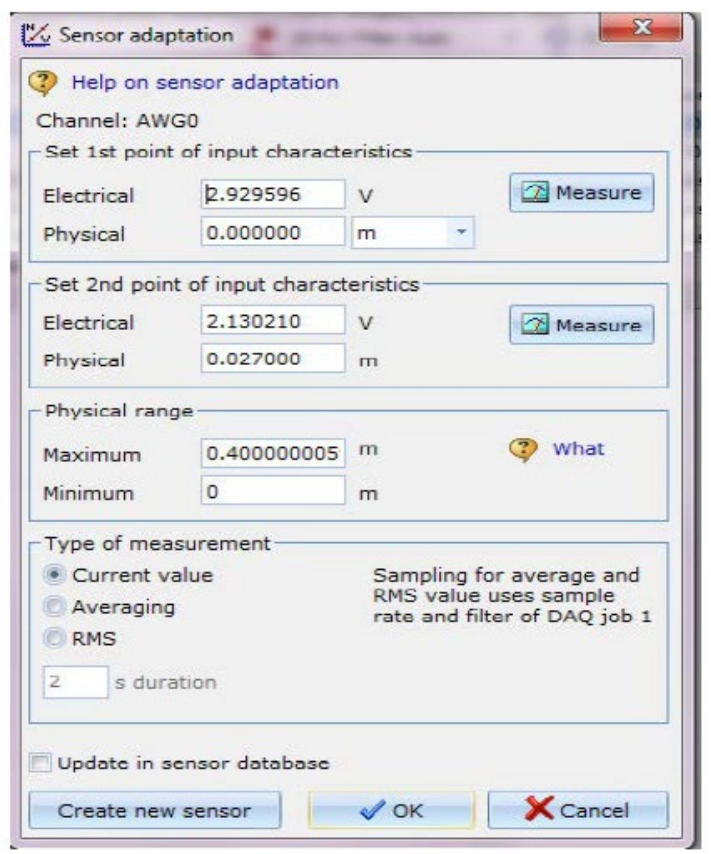

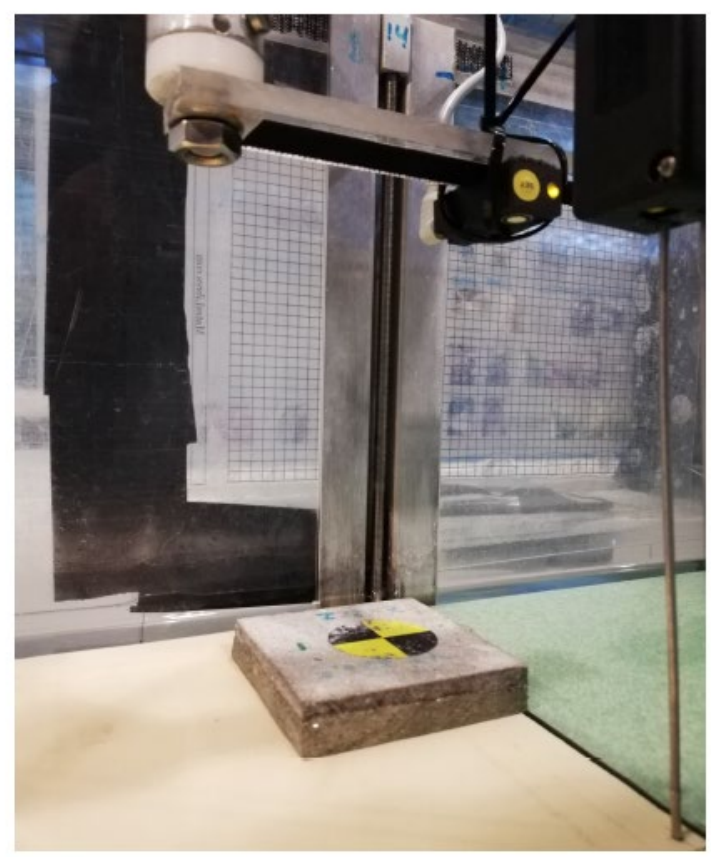

Figure 3.4: window of CatMan's for calibration process (left) and measurement with specimen (right)

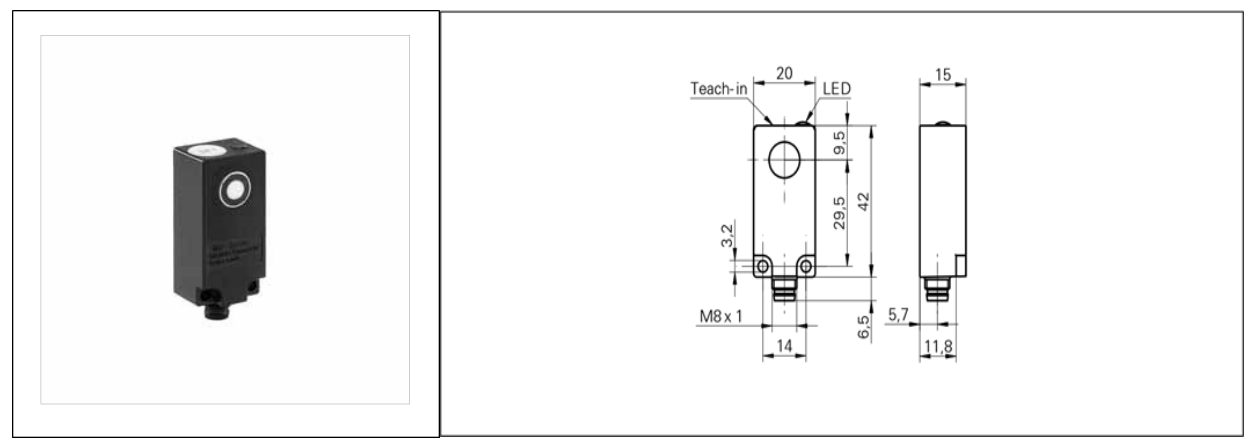

Figure 3.5: Ultrasonic sensor sample picture (left) and sample drawings (right).
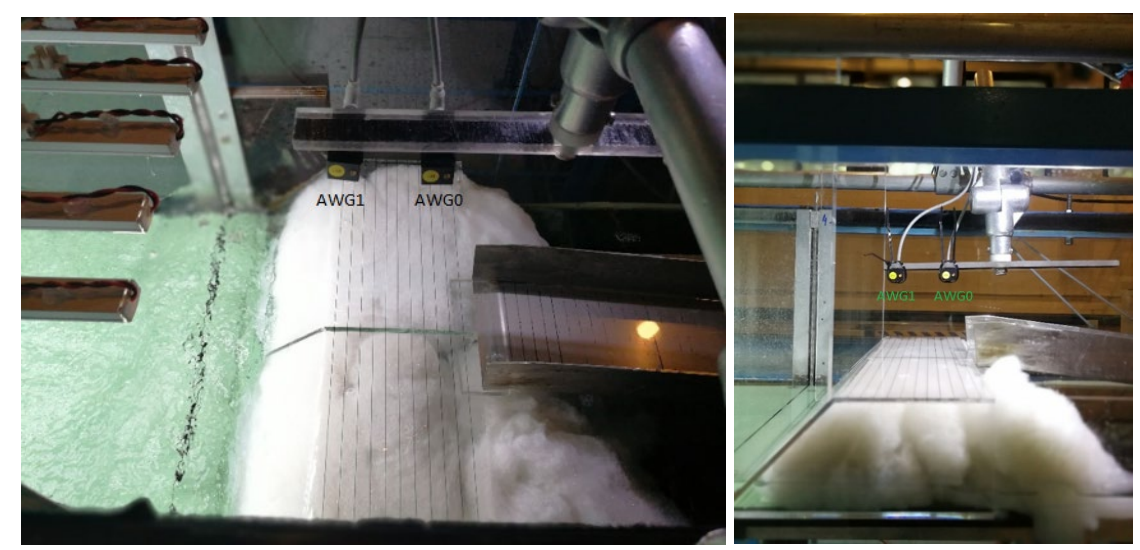

Figure 3.6: Ultrasonic sensors, top view (left); lateral view (right). 
Table 3.2: AWG technical features.

\begin{tabular}{|c|c|}
\hline \multicolumn{2}{|c|}{ General data } \\
\hline scanning range close limit Sdc & $60 \ldots 400 \mathrm{~mm}$ \\
\hline scanning range far limit Sde & $60 \ldots 400 \mathrm{~mm}$ \\
\hline repeat accuracy & $<0,5 \mathrm{~mm}$ \\
\hline Resolution & $<0,3 \mathrm{~mm}$ \\
\hline response time ton & $<60 \mathrm{~ms}$ \\
\hline release time toff & $<60 \mathrm{~ms}$ \\
\hline temperature drift & $<2 \%$ of distance to target So \\
\hline sonic frequency & $290 \mathrm{kHz}$ \\
\hline Adjustment & Teach-in \\
\hline alignment aid & target indication flashing \\
\hline light indicator & yellow LED / red LED \\
\hline \multicolumn{2}{|c|}{ Electrical data } \\
\hline voltage supply range +Vs & $15 \ldots 30 \mathrm{VDC}$ \\
\hline output current & $<20 \mathrm{~mA}$ \\
\hline residual ripple & $<10 \% \mathrm{Vs}$ \\
\hline short circuit protection & yes \\
\hline reverse polarity protection & yes \\
\hline \multicolumn{2}{|c|}{$\begin{array}{ll}\text { Voltage output } \\
\end{array}$} \\
\hline current consumption max. (no load) & $35 \mathrm{~mA}$ \\
\hline output signal & $0 \ldots 10 \mathrm{~V} / 10 \ldots 0 \mathrm{~V}$ \\
\hline \multicolumn{2}{|c|}{ Current output } \\
\hline Current consumption max (No load) & $55 \mathrm{~mA}$ \\
\hline Output signal & 4-20 mA/ 20-4 mA \\
\hline Load resistance + Vs max & $<1100 \mathrm{Ohm}$ \\
\hline Load resistanc +Vs min & $<400 \mathrm{Ohm}$ \\
\hline \multicolumn{2}{|c|}{ Mechanical data } \\
\hline Type & rectangular \\
\hline housing material & polyester \\
\hline width / diameter & $20 \mathrm{~mm}$ \\
\hline height / length & $42 \mathrm{~mm}$ \\
\hline Depth & $15 \mathrm{~mm}$ \\
\hline connection types & connector M8 \\
\hline \multicolumn{2}{|c|}{ Ambient conditions } \\
\hline operating temperature & $-10 \ldots+60^{\circ} \mathrm{C}$ \\
\hline protection class & IP 67 \\
\hline
\end{tabular}




\section{Data post-processing}

For data post-processing, including indirect velocity measurements, see details in Altomare et al. (2020). 


\section{Test program}

The in-house CiemGen v.1.2 software was used for wave generation. Irregular waves were tested. The value of spectra enhancement factor $\gamma$ which is fixed and equal to 3.30 for a standard JONSWAP spectrum. Employing same wave conditions $\left(\mathrm{H}_{\mathrm{m} 0}, \mathrm{~T}_{\mathrm{p}}\right)$, different time series can be generated varying a seed number, hence the phase assigned to each spectra wave component. More than four hundred tests were conducted during the thesis period, in which different conditions were considered depending on the slope of the beach, the promenade used and the desired return time. In the following tables it is possible to see all the combinations studied, expressed in model scale (1:50).

Table 5.1: tested wave conditions for 1:15 foreshore slope

\begin{tabular}{|l|l|l|l|l|l|l|}
\hline Slope & $T R[\mathrm{y}]$ & $\operatorname{Hm} 0[\mathrm{~m}]$ & $T p[\mathrm{~s}]$ & SEED & Depth [m] & Prom. [m] \\
\hline $1: 15$ & 1 & 0.085 & 1.69 & $1 ; 5$ & $0.29-0.30-0.31$ & $0.12-0.24$ \\
\hline $1: 15$ & 2 & 0.0882 & 1.74 & $1 ; 5$ & $0.29-0.30-0.31$ & $0.12-0.24$ \\
\hline $1: 15$ & 5 & 0.10 & 1.79 & $1 ; 5$ & $0.29-0.30-0.31$ & $0.12-0.24$ \\
\hline $1: 15$ & $>10$ & 0.11 & 1.4 & $1 ; 5$ & $0.29-0.30-0.31$ & $0.12-0.24$ \\
\hline $1: 15$ & $>10$ & 0.10 & $1.4-1.5-1.6$ & $1 ; 5$ & $0.29-0.30-0.31$ & $0.12-0.24$ \\
\hline $1: 15$ & $>10$ & 0.09 & $1.4-1.5-1.6-1.7$ & $1 ; 5$ & $0.29-0.30-0.31$ & $0.12-0.24$ \\
\hline
\end{tabular}

Table 5.2: tested wave conditions for 1:30 foreshore slope

\begin{tabular}{|l|l|l|l|l|l|l|}
\hline Slope & $T R[\mathrm{y}]$ & $H m 0[\mathrm{~m}]$ & $T p[\mathrm{~s}]$ & SEED & Depth [m] & Prom. [m] \\
\hline $1: 15$ & 1 & 0.085 & 1.69 & $1 ; 5$ & $0.29-0.30-0.31$ & $0.12-0.24$ \\
\hline $1: 15$ & 2 & 0.0882 & 1.74 & $1 ; 5$ & $0.29-0.30-0.31$ & $0.12-0.24$ \\
\hline $1: 15$ & 5 & 0.10 & 1.79 & $1 ; 5$ & $0.29-0.30-0.31$ & $0.12-0.24$ \\
\hline $1: 15$ & $>10$ & 0.11 & 1.4 & $1 ; 5$ & $0.29-0.30-0.31$ & $0.12-0.24$ \\
\hline $1: 15$ & $>10$ & 0.10 & $1.4-1.5-1.6$ & $1 ; 5$ & $0.29-0.30-0.31$ & $0.12-0.24$ \\
\hline $1: 15$ & $>10$ & 0.09 & $1.4-1.5-1.6-1.7$ & $1 ; 5$ & $0.29-0.30-0.31$ & $0.12-0.24$ \\
\hline
\end{tabular}




\section{Organization and structure of data files}

All data files are stored in a local hard drive at UPC. To access and receive the data, contact Dr. Corrado Altomare (email: corrado.altomare@upc.edu). The data is structured as followed:

- Directory "DATA" comprises:

1. Directory "_Incident": tests for determination of incident wave conditions;

2. Directory “_SPH”: overtopping results from mesheless Lagrangian DualSPHysics model (Crespo et al., 2015);

3. File "Test_Duration.txt": duration of each test case;

4. File "Results.txt": summary of all MatLab results;

5. Test directories, categorized per date and test number (TESTID=AAAAMMGG_\#\#), containing the data acquired during each test case. Each directory comprises:

- file TESTID_vol.TSX: metadata for overtopping volume;

- file TESTID_vol.txt: overtopping volume data (Sampling frequency $20 \mathrm{~Hz}$ ) and AWG data (sampling frequency $100 \mathrm{~Hz}$ );

- file TESTID.dat: raw data file for water surface elevation;

- file TESTID_conv.txt: converted data file for water surface elevation (Sampling Frequency $=80 \mathrm{~Hz}$;

Alternately, for all tests, recording with high-speed cameras have been carried out, so in tow subfolders can be found in the test directory containing frames of the two cameras (top-looking, CAM1; side-looking CAM-2).

In Table 6-1 the output file format for each measurement device is given.

Table 6.1: Output file specifications

\begin{tabular}{|c|c|c|c|c|}
\hline Data file & Type & \# heading lines & $\begin{array}{l}\text { Column: } \\
\text { Instrument [Unit] }\end{array}$ & Comments \\
\hline TESTID_vol.TSX & TypeScript & - & - & $\begin{array}{l}\text { Metadata of load cells } \\
\text { and AWG acquisition }\end{array}$ \\
\hline TESTID_vol.txt & ASCII & & $\begin{array}{l}\text { Time_f50Hz [s] } \\
\text { Time_f20Hz [s] } \\
\text { Time_f100Hz [s] } \\
\text { LC1 [kg] } \\
\text { LC2 [-1*kg] } \\
\text { AWG0 [m] } \\
\text { AWG1 [m] } \\
\text { SYNC [V] } \\
\text { LC1+abs(LC2) [kg] }\end{array}$ & $\begin{array}{l}\text { LC1 and LC2 are the } \\
\text { two load cells installed } \\
\text { below the overtopping } \\
\text { tank. Based on the } \\
\text { assembly direction, the } \\
\text { LC2 was giving } \\
\text { negative values in } \\
\text { output. }\end{array}$ \\
\hline TESTID.dat & $\begin{array}{l}\text { WaveLab3 } \\
\text { Data File } \\
\text { (ASCII) }\end{array}$ & 102 & $\begin{array}{l}\text { WG0 [V] } \\
\text { WG1 [V] } \\
\text { WG2 [V] } \\
\text { WG3 [V] } \\
\text { WG4 [V] } \\
\text { WG5 [V] } \\
\text { WG6 [V] } \\
\text { WG7 [V] }\end{array}$ & $\begin{array}{l}\text { File with raw data of } \\
\text { water surface } \\
\text { elevation, including } \\
\text { calibration coefficients } \\
\text { and offsets. }\end{array}$ \\
\hline
\end{tabular}




\begin{tabular}{|l|l|l|l|l|}
\hline & & & $\begin{array}{l}\text { DEMMAND [V] } \\
\text { FEEDBACK [V] } \\
\text { SYNC [V] }\end{array}$ & \\
\hline TESTID_conv.txt & ASCII & 6 & $\begin{array}{l}\text { WG0 [m] } \\
\text { WG1 [m] } \\
\text { WG2 [m] } \\
\text { WG3 [m] } \\
\text { WG4 [m] } \\
\text { WG5 [m] } \\
\text { WG6 [m] } \\
\text { WG7 [m] } \\
\text { DEMAND [m] } \\
\text { FEEDBACK [m] } \\
\text { SYNC [V] }\end{array}$ & $\begin{array}{l}\text { File with converted } \\
\text { data of water surface } \\
\text { elevation and } \\
\text { wavemaker } \\
\text { displacement }\end{array}$ \\
& & & \\
& & & \\
& & & \\
\end{tabular}




\section{$7 \quad$ References}

- Altomare C., Gironella X., Suzuki T., Viccione G., Saponieri, A. (2020). Overtopping Metrics and Coastal Safety: A Case of Study from the Catalan Coast. J. Mar. Sci. Eng., 8, 556. https://doi.org/10.3390/jmse8080556

- Crespo A.J.C., Domínguez J.M., Rogers B.D., Gómez-Gesteira M., Longshaw S., Canelas R., Vacondio R., Barreiro A., García-Feal O. (2015). DualSPHysics: open-source parallel CFD solver on Smoothed Particle Hydrodynamics (SPH). Computer Physics Communications, 187: 204-216. doi: 10.1016/j.cpc.2014.10.004.

- EurOtop (2018). Manual on wave overtopping of sea defences and related structures. An overtopping manual largely based on European research, but for worldwide application. Van der Meer, J.W., Allsop, N.W.H., Bruce, T., De Rouck, J., Kortenhaus, A., Pullen, T., Schüttrumpf. 